\title{
Zur Benachrichtigung
}

Die Atomgewichtskommission der Internationalen Union für Chemie veröffentlicht alljährlich die dem augenblicklichen Stande der Forschung entsprechènden Atomgewichtszahlen. Die vorliegende Auflage ist mit den für 1939 gültigen Werten berechnet worden.

A. Thiel.

Man beachte die Vorbemerkungen! 

Arbeitsmethoden der modernen Naturwissenschaften 
